\title{
Новітні терапевтичні можливості в лікуванні хронічної серцевої недостатності
}

\author{
А.Р. Хиць \\ Редакція журналу «Український медичний часопис»
}

У рамках проєкту «Сучасна та майбутня перспектива лікування серцевої недостатності» відбувся цикл науково-практичних вебінарів «Новітні терапевтичні можливості в лікуванні хронічної серцевої недостатності», спікерами якого виступили Леонід Воронков, доктор медичних наук, професор, керівник відділу серцевої недостатності Національного наукового центру (ННЦ) «Інститут кардіології ім. акад. М.Д. Стражеска» Національної академії медичних наук (НАМН) України, Олександр Пархоменко, доктор медичних наук, професор, член-кореспондент НАМН України, керівник відділу реанімації та інтенсивної терапії ННЦ «Інститут кардіології ім. акад. М.Д. Стражеска» НАМН України, Ярослав Лутай, кандидат медичних наук, старший науковий співробітник відділу реанімації та інтенсивної терапії ННЦ «Інститут кардіології ім. акад. М.Д. Стражеска» НАМН України, та Тарас Чендей, кандидат медичних наук, доцент кафедри внутрішніх хвороб Ужгородського національного університету.

Леонід Воронков виступив з доповіддю «Серцева недостатність: еволюція підходів», в якій детально зупинився на нових підходах у лікуванні пацієнтів із серцевою недостатністю (CH). Незважаючи на значні успіхи у вивченні патофізіології СН та істотний прогрес у галузі фармакотерапії, СН залишається надзвичайно складним для лікування захворюванням. Статистичні дані свідчать, що в загальній структурі смертності СН займає провідне положення, випереджаючи такі поширені злоякісні хвороби, як рак підшлункової залози і сечового міхура у чоловіків і рак молочної залози у жінок [1]. Однак упродовж останніх років удосконалення терапії СН та ії впровадження у клінічну практику поліпшило показник виживання пацієнтів цієї групи. Так, результати нещодавнього аналізу бази даних 1,75 млн пацієнтів (50 тис. 3 них - із СН), які отримували первинну медико-санітарну допомогу в Шотландії, показав, що показник 5-річного виживання у хворих із СН на фоні фармакотерапії становив близько 50\% [2]. Ці дані свідчать, що застосування відповідної фармакотерапії, спрямованої на блокування різних ланок прогресування $\mathrm{CH}$, зумовлює поліпшення прогнозу у пацієнтів цієї групи.

Історія лікування СН налічує вже близько 200 років. Перші згадки про лікування СН беруть початок у 1785 р., коли англійський ботанік W. Withering опублікував результати успішного лікування «серцевої водянки» свіжим листям наперстянки [3]. Сучасна історія лікування $\mathrm{CH}$ за допомогою нових фармакотерапевтичних методів почалася 3 інгібіторів ангіотензинперетворювального ферменту (іАПФ). Перший іАПФ - каптоприл - було синтезовано у 1976 р. Широке застосування іАПФ у схемах лікування СН починає свій відлік з 1991 р., коли були опубліковані результати дослідження SOLVD (Studies of Left Ventricular Dysfunction), в якому продемонстровано, що на фоні прийому іАПФ (еналаприл) показник виживання пацієнтів із $\mathrm{CH}$ достовірно підвищувався, а смертність від прогресування СН та раптова смертність знижувалися на 16\% [4]. Починаючи з 1990-х років, іАПФ з'явилися в американських рекомендаціях з лікування $\mathrm{CH}$, в яких рекомендовано призначати іАПФ всім хворим із систолічною дисфункцією лівого шлуночка в якості препаратів 1-ї лінії незалежно від наявності або відсутності у них клінічних симптомів СН. Відповідно до цих рекомендацій всі інші лікарські препарати визначені як доповнення до базисної терапії іАПФ. Відповідно до сучасних гайдлайнів іАПФ $\epsilon$ рекомендованими препаратами для лікування $\mathrm{CH}$, механізм дії яких полягає в пригніченні утворення ангіотензину II та стимуляції брадикініну, вазодилататорних простагландинів та оксиду азоту (рис. 1).

Корекція підвищеної активності симпатоадреналової системи за допомогою застосування блокаторів $\beta$-адренорецепторів при лікуванні пацієнтів із $\mathrm{CH}$ починає свій відлік з оприлюднення наприкінці 1990-х років клінічних результатів мультицентрових рандомізованих плацебо-контрольованих досліджень - US Carvedilol Heart Failure Program (USCP, 1996), CIBIS-II (1999), MERIT-HF (1999) та COPERNICUS (2001), що охопили загалом >10 тис. хворих. Результати цих досліджень продемонстрували, що застосування блокаторів $\beta$-адренорецепторів (карведилолу, бісопрололу та ретардної фор- ми метопрололу сукцинату - метопрололу $(\mathrm{R} / \mathrm{XL}$ ) приблизно на третину знижувало смертність пацієнтів порівняно з тими, хто приймав плацебо додатково до терапії іАПФ і діуретиком [5].

Для зниження гіперактивації ренін-ангіотензин-альдостеронової системи (РАAC) у 2010 р. до терапії СН додані антагоністи мінералокортикоїдних рецепторів (АМР). Як відомо, альдостерон $\epsilon$ одним з основних факторів, що викликають затримку рідини в організмі й активний іонний обмін в дистальних канальцях нирок, що призводить до втрати організмом калію і магнію, розвитку симптомів $\mathrm{CH}$, тобто до набрякового синдрому (рис. 2). Відповідно AMP, блокуючи РАAC, зменшують гіпертрофію міокарда та прогресування кардіосклерозу. Так, у дослідженні EMPHASIS-HF (2011) показано, що застосування селективних AMP (еплеренон) у пацієнтів із $\mathrm{CH}$ асоційоване зі зниженням ризику загальної смерті на $24 \%$ і госпіталізації на $42 \%$ [6].

У 2014 р. значним проривом у лікуванні СН стали підсумки подвійного сліпого рандомізованого дослідження комбінації інгібіторів рецепторів ангіотензину та неприлізину (IPAH) (комбінація сакубітрил/валсартан), що забезпечує блокаду як патогенних ефектів PAAC, так і блокаду неприлізину [8]. Згідно з отриманими результатами у пацієнтів, які застосовували сакубітрил/валсартан, комбінований показник смертності внаслідок серцево-судинної патології та госпіталізації у зв'язку із СН знизився на 20\%, смертність, спричинена серцево-судинною патологією, - також на 20\%, показник першої госпіталізації внаслідок $\mathrm{CH}$ - на 21\% та загальна смертність - на 16\%. Позитивний ефект комбінації досягається за рахунок блокування РАAC та неприлізину - фермент, який бере участь у розпаді вазоактивних речовин, таких як натрійуретичний пептид (НУП), брадикінін та адреномедулін. При СН підвищений вміст ендотеліну, аргінін-вазопресину і катехоламінів сприяє стимулюванню синтезу і вивільненню НУП. Як відомо, НУП мають захисні властивості щодо серцево-судинної системи, зниження активності РААС та гальмування проліферативних процесів, сприяють блокуванню вивільнення альдостерону, виявляють натрійуретичний ефект і знижують тонус судин. Таким чином, кардіопротекторні властивості НУП при СН вкрай важливі. Відповідно, застосування інгібіторів

Рисунок 1 Механізм дії іАПФ

\begin{tabular}{|c|c|c|c|}
\hline \multicolumn{4}{|c|}{ іАПФ } \\
\hline$\downarrow$ & \multicolumn{3}{|c|}{$\downarrow$} \\
\hline $\begin{array}{c}\text { Пригнічення утворення } \\
\text { ангіотензину II }\end{array}$ & \multicolumn{3}{|c|}{$\begin{array}{c}\text { Стимуляція брадикініну, вазодилататорних } \\
\text { простагландинів, оксиду азоту }\end{array}$} \\
\hline$\downarrow$ & $\downarrow$ & $\downarrow$ & $\downarrow$ \\
\hline $\begin{array}{l}\text { Гальмування його шкідливих ефектів: } \\
\text { • вазоконстрикція }\end{array}$ & Вазодилатація & $\begin{array}{c}\text { Протромботич- } \\
\text { ний ефект }\end{array}$ & $\begin{array}{c}\text { Захист } \\
\text { ендотелію }\end{array}$ \\
\hline $\begin{array}{l}\text { - затримка рідини } \\
\text { - гіпертрофія міокарда } \\
\text { • нефросклероз } \\
\text { - утворення вільних радикалів }\end{array}$ & & & \\
\hline
\end{tabular}


Рисунок 2 Вплив альдостерону на організм [7]

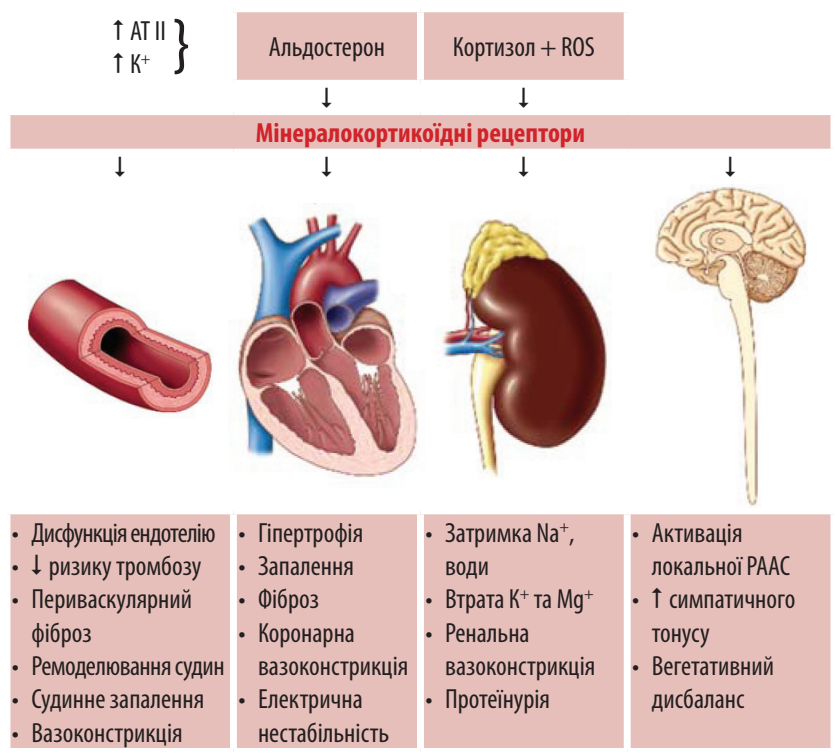

ROS — оксидативний стрес; AT II — ангіотензин II типу.

неприлізину - важлива ланка фармакотерапії серцево-судинних захворювань (СС3), зокрема $\mathrm{CH}$.

Аналізуючи еволюцію поглядів на лікування $\mathrm{CH}$, стає зрозумілим, що кожне «оновлення» у лікування $\mathrm{CH}$ асоціювалося $з$ покращенням прогнозу виживання пацієнтів цієї групи (рис. 3). Ці висновки підтверджуються результатами нещодавно опублікованого дослідження R.J.H. Miller та співавторів (2020), які продемонстрували, що смертність пацієнтів із СН та зниженою фракцією викиду (ФВ) лівого шлуночка (ЛШ) впродовж 1-го року залежить від терапії. Так, серед пацієнтів, які не отримували терапію нейрогуморальними антагоністами (НА), смертність становила 17\%, серед пацієнтів, які отримували терапію іАПФ та блокаторами $\beta$-адренорецепторів, - 9,4\%, пацієнти, які отримували терапію iАПФ + блокаторами $\beta$-адренорецепторів + AMP, - 7\% і найкращий показник виживання був у групі терапії сакубітрил/валсартан + блокатори $\beta$-адренорецепторів + АМР, він становив 5,6\% (рис. 4) [9].

Олександр Пархоменко у своїй доповіді детально зупинився на сучасних даних щодо ефективності та безпеки терапії інгібіторами натрійзалежного котранспортера глюкози 2-го типу (іНЗКТГ-2) у лікуванні СН. В останні роки в світі за рахунок збільшення середньої тривалості життя та успіхів в лікуванні СС3 спостерігають значне збільшення числа пацієнтів із СН. Незважаючи на досягнення у фармакотерапії, СН й досі асоціюється зі значним ризиком смертності, частота якої сягає 20\%, або госпіталізації з приводу СН [10]. Відповідно, основними цілями лікування $\mathrm{CH} \in$ зниження госпіталізації, підвищення показника виживання, зменшення вираженості симптомів захворювання та покращення якості життя пацієнтів.

За останні роки з'явилося кілька принципово нових фармакологічних підходів, здатних впливати на прогноз пацієнтів із $\mathrm{CH}$, зокрема, це твердження стосується застосування іНЗКТГ-2 з метою прогноз-визначальної терапії СН. Відповідно до рекомендацій Всеукраїнської асоціації кардіологів України та Всеукраїнської асоціації фахівців із серцевої недостатності «Серцева недостатність у хворих на цукровий діабет» 2020 р., призначення іНЗКТГ-2 може розглядатися у хворих із СН зі зниженою ФВ ЛШ і цукровим діабетом (ЦД) 2-го типу, які отримують терапію за рекомендованою схемою (іАПФ або блокатор рецепторів ангіотензину II (БРА) або сакубітрил/валсартан + блокатор $\beta$-адренорецепторів + AMP) для поліпшення віддаленого прогнозу та зниження смертності [11]. У документі зазначено, що іНЗКТГ-2 повинні застосовуватися в усіх пацієнтів із СН та зниженою ФВ ЛШ якомога швидше, додатково або разом з рекомендованими препаратами класу Іа (блокатори $\beta$-адренорецепторів, іАПФ/БРА і AMP), а також додатково до IPAН. У 2021 р. опубліковані оновлені рекомендації Американської колегії кардіологів (American College of Cardiology - ACC), в яких висвітлені нюанси «нових» методів лікування СН, включно і застосуванням іНЗКТГ-2 (рис. 5) [12]. Ці реко-
Рисунок 3 Еволюція прогнозмодулювальної терапії СH

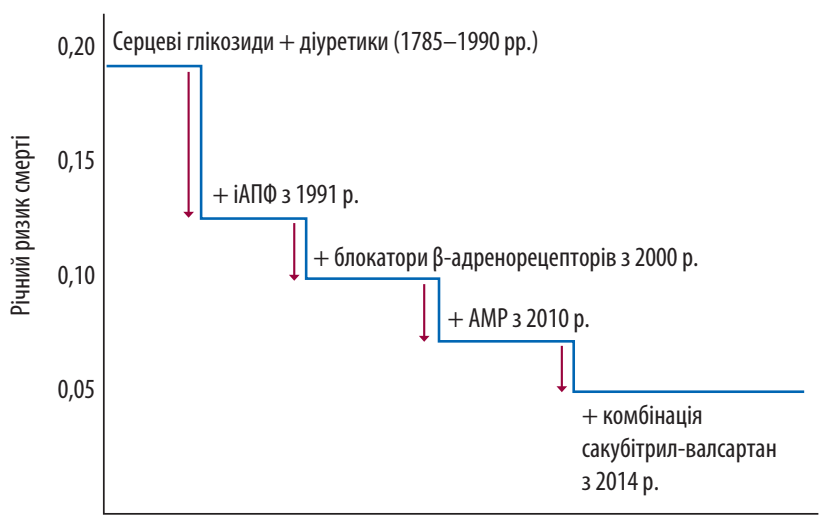

Рисунок 4 Смертність пацієнтів з СН впродовж 1-го року

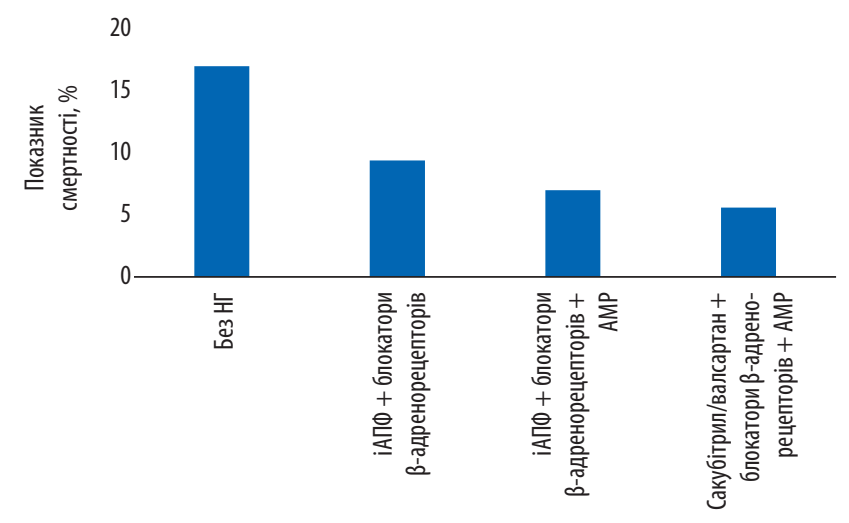

мендації базуються на результатах двох важливих міжнародних досліджень DAPA-HF та EMPEROR-Reduced.

DAPA-HF - міжнародне мультицентрове плацебо-контрольоване клінічне дослідження фази 3, в якому оцінювали вплив антигіперглікемічних препаратів з групи іНЗКТГ-2 (дапагліфлозин) на лікування пацієнтів із СН на фоні ЦД 2-го типу та без нього, в якому брали участь 4744 пацієнтів із CH (NYHA II-IV) і ФB <40\% [13]. Результати дослідження продемонстрували, що застосування іНЗКТГ-2 (дапагліфлозин) $\epsilon$ ефективною стратегією лікування пацієнтів із хронічною $\mathrm{CH}$ зі зниженою ФВ, яка асоціювалася зі зниженням відносного ризику серцево-судинної смерті на 18\%, смерті від усіх причин - на 17\% та частоти госпіталізацій - на 30\%. Зазначений ефект спостерігали у пацієнтів із/без ЦД. Також спікер відмітив, що дапагліфлозин достовірно знижував ризик серцево-судинної смерті, госпіталізації або термінового візиту з приводу СН вже на 28 добу, що свідчить про швидкий ефект від застосування препарату. Також важливим $\epsilon$ те, що зазначений ефект спостерігався незалежно від фонової стандартної терапії СН. Таким чином, продемонстровано, що застосування дапагліфлозину при додаванні до стандартної схеми лікування у пацієнтів із СН зі зниженою ФВ ЛШ зумовлює зниження ризику погіршення СН і серцево-судинної смерті, загальної смертності, а також зменшення вираженості клінічних проявів $\mathrm{CH}$.

EMPEROR-Reduced - міжнародне плацебо-контрольоване дослідження фази 3, в якому оцінювали ефективність застосування іНЗКТГ-2 (емпагліфлозину) при серцево-судинних та ниркових подіях при СН зі зниженою ФВ ЛШ [14]. Його результати продемонстрували, що у пацієнтів з СН можливо покращити прогноз за рахунок зниження ризику серцево-судинної смертності та госпіталізації з приводу СН на 25\%. Таким чином, результати двох досліджень DAPA-HF і EMPEROR-Reduced підтверджують необхідність впровадження у клінічну практику нового підходу до лікування $\mathrm{CH}$, що підвищує важливість застосування іНЗКТГ-2 у пацієнтів із СН та зниженою ФВ. Це змусило міжнародні медичні товариства внести корективи в рекомендації щодо базової фармакотерапії СН (рис. 6).

Ярослав Лутай у своїй доповіді оприлюднив сучасні дані щодо профілю безпеки іНЗКТГ-2 у пацієнтів із $\mathrm{CH}$, фокусуючи увагу на найбільш суттєвих побічних реакціях, асоційованих із терапією іНЗКТГ-2, таких як розвиток гіпоглікемії та діабетичного кетоацидозу (ДК). 
Рисунок 5 Алгоритм фармакологічної терапії СН, орієнтований на рекомендації ACC

\begin{tabular}{|c|c|c|c|c|}
\hline \multicolumn{5}{|c|}{ СН зі зниженою ФВ ЛШ (стадія С) лікування } \\
\hline (переважно & АН) та блокато & $\begin{array}{r}\text { IPAН/іАПФ/БР } \\
\text { ß-адренорецеп }\end{array}$ & рів з діуретиками & необхідності \\
\hline$\downarrow$ & $\downarrow$ & $\downarrow$ & $\downarrow$ & $\downarrow$ \\
\hline $\begin{array}{c}\text { Для пацієнтів } \\
\text { з рШКФ >30 мл/ } \\
\text { хв/1,73 м² } \\
\text { або } \\
\text { креатиніном } \\
<2,5 \text { мг/дл для } \\
\text { чоловіків } \\
\text { та <2,0 мг/дл } \\
\text { для жінок } \\
\text { або } \\
\mathrm{K}^{+}<5 \text { ммоль/л } \\
\text { NYHА II-ІV }\end{array}$ & $\begin{array}{c}\text { Для пацієнтів, } \\
\text { які } \\
\text { відповідають } \\
\text { рШКФ } \\
\text { NYHA II-IV }\end{array}$ & $\begin{array}{c}\text { Для пацієнтів } \\
\text { зі стійким } \\
\text { о6'ємним } \\
\text { перевантажен- } \\
\text { ням } \\
\text { NYHA II-IV }\end{array}$ & $\begin{array}{c}\text { Для пацієнтів } \\
\text { негроїдної раси } \\
\text { зі стійкими } \\
\text { симптомами, } \\
\text { незважаючи } \\
\text { на терапію IPAH/ } \\
\text { АMP/iHЗКTГ-2 } \\
\text { NYHA II-IV }\end{array}$ & $\begin{array}{c}\text { Для пацієнтів із } \\
\text { ЧСС у стані спокою } \\
>70 \text { уд./хв, } \\
\text { на максимально } \\
\text { переносимій дозі } \\
\text { блокатора } \\
\text { В-адрено- } \\
\text { рецепторів } \\
\text { при синусовому } \\
\text { ритмі }\end{array}$ \\
\hline$\downarrow$ & $\downarrow$ & $\downarrow$ & $\downarrow$ & $\downarrow$ \\
\hline Додати & Додати & Титрува & Додати & Додати \\
\hline$\downarrow$ & $\downarrow$ & $\downarrow$ & $\downarrow$ & $\downarrow$ \\
\hline AMP & інЗКТГ-2 & Діуретик & $\begin{array}{c}\text { Гідралазин } \\
+ \\
\text { ізосорбіду динітрат }\end{array}$ & Івабрадин \\
\hline
\end{tabular}

рШКФ — розрахункова швидкість клубочкової фільтрації; ЧСС — частота серцевих скорочень.

Рисунок 6 Сучасна базова терапія СH [15]

\begin{tabular}{|l|c|c|c|c|}
\hline \multicolumn{5}{|c|}{ Базова терапія в лікуванні СН зі зниженою ФВ ЛШ для зниження смертності } \\
\hline IPAН & ІАПФ або БРА & АМР & $\begin{array}{c}\text { Блокатори } \\
\text {-адренорецепторів }\end{array}$ & iНЗКТГ-2 \\
\hline
\end{tabular}

Враховуючи те, що іНЗКТГ-2 першочергово $\epsilon$ антигіперглікемічними препаратами, значна частина кардіологів переймаються щодо ризику розвитку гіпоглікемії на фоні терапії препаратами цієї групи. Однак результати попередньо опублікованих досліджень демонстрували, що застосування іНЗКТГ-2 не асоціювалося з ризиком розвитку гіпоглікемії. Так, у дослідженні DAPA-HF частота розвитку гіпоглікемії була рідкісною і однаковою за частотою $(0,2 \%)$ в групі дапагліфлозину і плацебо, незалежно від статусу цД. Однакова частота гіпоглікемії в групі іНЗКТГ-2 та плацебо свідчить, що її розвиток асоційований не з прийомом іНЗКТГ-2, а з фоновою терапією, яку отримували пацієнти, та іншими факторами ризику.

Фактори ризику гіпоглікемії:

- діагноз ЦД 2-го типу протягом тривалого часу;

- макросудинні ускладнення (інсульт, інфаркт міокарда);

- погіршення функції нирок (хронічна хвороба нирок), макроальбумінерія;

- коронарна реваскуляризація;

- госпіталізація у відділення інтенсивної терапії;

- необізнаність щодо гіпоглікемії;

- похилий вік;

- когнітивна функція;

- прийом інсуліну та препаратів сульфонілсечовини [16].

Внаслідок відносно високого рівня глюкагону на фоні прийому гліфлозинів може бути наявним незначний ризик розвитку ДК (0,1-0,4\% випадків). Однак результати дослідження DAPA-HF щодо профілю безпеки дапагліфлозину цього не підтвердили, адже не було статистичної різниці між випадками у групі дапагліфлозину та плацебо. Цей факт вказує на те, що ризик ДК може бути асоційований з інсулінотерапією та іншими факторами ризику, включно 3 голодуванням, а не з терапією іНЗКТГ-2 (таблиця). Також спікер відмітив, що важливим фактором профілю безпеки іНЗКТГ-2 $\epsilon$ те, що вони мають незначний вплив на артеріальний тиск, враховуючи, що у значної кількості пацієнтів з СН зі зниженою ФВ відзначається тенденція до гіпотензії. Що стосується інших побічних реакцій, які становлять інтерес, зокрема небажаних явищ з боку нирок (або впливу на функцію нирок), гіповолемії, ампутації нижніх кінцівок, асоційованих з терапією іНЗКТГ-2, то їх частота у до- слідженнях DAPA-HF та EMPEROR-Reduced суттєво не відрізнялася між групами (рис. 7).

Таблиця Фактори ризику ДК, асоційовані з іНЗКТГ-2

\begin{tabular}{|c|c|}
\hline \multicolumn{2}{|c|}{ Фактори ризику ДК } \\
\hline Високий/середній ризик & Середній/низький ризик \\
\hline $\begin{array}{l}\text { - Зниження базальної дози інсуліну більш } \\
\text { ніж на 20\% } \\
\text { • Дефіцит інсуліну (у пацієнтів на інсуліно- } \\
\text { вій помпі) } \\
\text { • Обмеження вуглеводів (різкий дефіцит) } \\
\text { • Вживання алкоголю } \\
\text { • Дегідратація/зневоднення } \\
\text { - Гострий інфекційний процес } \\
\text { • Блювання }\end{array}$ & $\begin{array}{l}\text { • } \text { Зниження прандіальної дози інсуліну } \\
\text { на >20\% } \\
\text { - Порушення режиму введення } \\
\text { - Використання інсулінової помпи } \\
\text { - Дефіцит кілокалорій в їжі } \\
\text { - Вживання алкоголю }\end{array}$ \\
\hline
\end{tabular}

Враховуючи те, що іНЗКТГ-2 нещодавно рекомендовані до застосування при $\mathrm{CH}$, досвід їх клінічного застосування у нашій країні обмежений. Тарас Чендей у своїй доповіді «Практичні аспекти використання іНЗКТГ-2 при СН» навів власний клінічний досвід ефективності застосування іНЗКТГ-2 (дапагліфлозин) при лікуванні СН.

Починаючи свою доповідь, спікер зазначив, що при менеджменті пацієнтів з СН першочерговим $\epsilon$ визначення цілей лікування, але клінічний досвід свідчить, що часто цілі лікування у лікаря та пацієнта не збігаються. I якщо пацієнт очікує від лікування покращення самопочуття, відсутність обмежень фізичної активності та повернення до звичного способу життя, то клініцист, при виборі терапії, враховує: вплив на прогноз, зниження ризику госпіталізації, профіль безпеки та зручність застосування.

\section{Клінічний випадок № 1}

Пацієнт, 62 роки. Діагноз: «Ішемічна хронічна серцева недостатність». Звернувся зі скаргами на помірні симптоми СН (задишка, втомлюваність, серцебиття при фізичних навантаженнях, що перевищують звичні). Застосовував ацетилсаліцилову кислоту в дозі 75 мг/добу. Пацієнт не дотримувався рекомендацій щодо лікування та самостійно змінив призначення.

Анамнез: ЦД 2-го типу протягом 11 років, артеріальна гіпертензія. Повторні епізоди набряку легень. Не переносить блокатори $\beta$-адренорецепторів через бронхоспазм. У 2015 р. проведено планове стентування передньої міжшлуночкової артерії. У 2016 р. нижній інфаркт міокарда, проведено ургентне стентування правої коронарної артерії.

Попередня терапія: метформін 2000 мг/добу, периндоприл 5 мг/ добу, спіронолактон 25 мг/добу, івабрадин 7,5 мг 1 раз на добу, торасемід 5 мг/добу, аторвастатин 80 мг/добу, ацетилсаліцилова кислота.

Обстеження: ФВ ЛШ 32\%, ШКФ 76 мл/хв/1,73 м², рівень холестерину ліпопротеїдів низької щільності 2,94 ммоль/л, глюкоза 11,19 ммоль/л. Артеріальний тиск 110/70 мм рт. ст., ЧСС 64 уд./хв.

Поточне лікування (самолікування): метформін 500 мг/добу, периндоприл 5 мг/добу, івабрадин 5 мг 2 рази на добу, аторвастатин 20 мг/добу, ацетилсаліцилова кислота 75 мг/добу.

Після обстеження стану пацієнта та спираючись на поточні рекомендації щодо лікування СН здійснена корекція терапії: замість метформіну рекомендована фіксована комбінація дапагліфлозин/метформін XR 10/1000 та підвищена доза аторвастатину з 20 до 40 мг/ добу. Через 4 дні після призначеного лікування, пацієнт телефонує лікареві та повідомляє, що не бажає продовжувати лікування фіксованою комбінацією через наявність побічних симптомів циститу (часте сечопускання). У такому разі, зазначає Т. Чендей, важливо провести 3 пацієнтом додаткову бесіду і роз'яснити, що поява частого сечопускання ніяк не пов'язана з будь-якою інфекцією сечовидільних шляхів. Після проведеної бесіди, в ході якої лікар пояснив, що часте сечопускання $\epsilon$ короткочасним явищем, яке мине через 2 тиж, пацієнт продовжив терапію фіксованою комбінацією.

Через 2 міс терапії пацієнт звернувся до лікаря зі стурбованістю щодо підвищення рівня креатиніну при контрольному лабораторному дослідженні і відповідно можливого негативного впливу на функцію нирок. У такому разі також необхідно провести бесіду з пацієнтом та пояснити йому, що упродовж перших місяців від початку лікування дапагліфлозином можливе підвищення рівня креатиніну 
Рисунок 7 Побічні ефекти, асоційовані з терапією іНЗКТГ-2 [17] А. Результати дослідження DAPA-HF

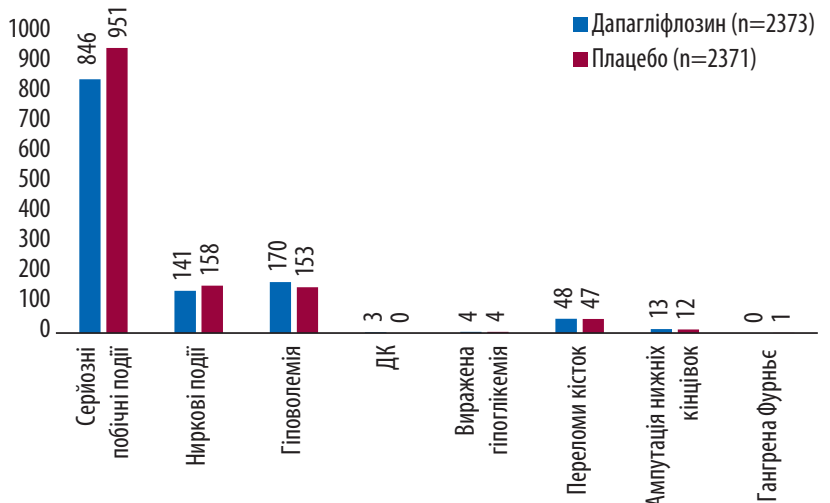

B. Результати дослідження EMPEROR-Reduced

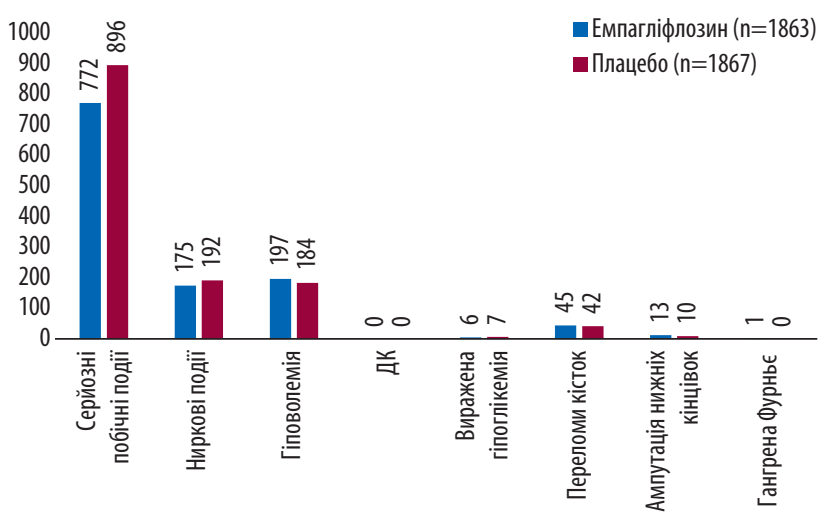

і зниження швидкості клубочкової фільтрації, і це $є$ варіантом норми, оскільки в довготерміновій перспективі це забезпечує виражений нефропротекторний ефект. Цей ефект було продемонстровано в дослідженні DAPA-CKD, результати якого показали, що транзиторне зниження швидкості клубочкової фільтрації є відображенням нефропротекторних властивостей дапагліфлозину [18].

Підсумовуючи, спікер зазначив, що такий клінічний випадок не $\epsilon$ рідкістю, і часто пацієнти плутають симптоми дизурії та поліурії, що, відповідно, призводить до відміни терапії. Такі клінічні випадки часто проходять повз увагу лікарів і помилково інтерпретується як інфекції сечовидільних шляхів. Тому клініцисти, які здійснюють менеджмент пацієнтів із $\mathrm{CH}$, повинні знати та розуміти профіль безпеки препаратів, які вони призначають. Результати дослідження DAPA-HF продемонстрували, що препарат дапагліфлозину має доведений профіль безпеки, а частота будь-яких побічних реакцій на фоні терапії не відрізнялася від плацебо. Також дослідження підтвердило, що ефективність дапагліфлозину і його кардіопротективні та нефропротективні властивості є доведеними і не залежать від вихідного рівня швидкості клубочкової фільтрації.

\section{Клінічний випадок № 2}

Пацієнтка, 79 років. Діагноз: «Неішемічна хронічна серцева недостатність». Звернулася зі скаргами на виражені симптоми СН (значна втомлюваність, задишка, обмежена фізична активність).

Анамнез: хворіє на СН впродовж 5 років, неодноразові декомпенсації. Прогресивне зниження ФВ ЛШ (38-22\%). Наявна супутня залізодефіцитна анемія, блокада лівої ніжки пучка Гіса.

Обстеження: ФВ ЛШ 20\%, ШКФ 51 мл/хВ/1,73 м², калій 4,3 ммоль/л. Ангіографія - без істотних змін. Артеріальна гіпертензія відсутня. Артеріальний тиск 104/62 мм рт. ст., ЧСС 62 уд./Хв, еуволемія. Маса тіла 52 кг, зріст 156 см.

Поточне лікування: карведилол 25 мг/добу, фуросемід 40 мг/ добу, спіронолактон 25 мг/добу, сакубітрил/валсартан 100 мг/добу, ацетилсаліцилова кислота 75 мг/добу.

Пацієнтка дотримувалася усіх рекомендацій з лікування. Після обстеження та спираючись на поточні рекомендації щодо лікування СН пацієнтці додано до терапії дапагліфлозин 10 мг/добу. Після призначеного лікування пацієнтка відмічає суттєве покращення загального самопочуття (зменшилася вираженість симптомів, покращилася здатність до фізичного навантаження, підвищення рівня гемоглобіну, ФВ ЛШ 29 \%). Наведений клінічний випадок наглядно продемонстрував, що дапагліфлозин є ефективним у даної когорти пацієнтів незалежно від етіології СН (ішемічна або неішемічна), віку, базового рівня фракції викиду, а також прийому діуретиків й іншої стандартної терапії на вихідному рівні.

Таким чином, враховуючи реальний клінічний досвід застосування та дані попередніх досліджень щодо ефективності дапагліфлозину на покращення прогнозу, зниження ризику госпіталізацій, поліпшення симптомів та значне покращення якості життя, а також доведений профіль безпеки і зручність застосування, можна зробити висновок, що впровадження дапагліфлозину у клінічну практику $\epsilon$ ефективною стратегією лікування $\mathrm{CH}$. Сьогодні дапагліфлозин $\epsilon$ схваленим Управлінням з контролю за якістю харчових продуктів і лікарських засобів США (U.S. Food and Drug Administration - FDA) та Європейським агентством з лікарських засобів (European Medicines Agency — EMA) для лікування СН зі зниженою ФВ.

\section{Список використаної літератури/References:}

1. Stewart S., Macintyre K., Hole D.J. et al. (2001) More 'malignant' than cancer? Five-year survival following a first admission for heart failure. Eur. J. Heart Fail., 3(3): 315-322. doi: 10.1016/s13889842(00)00141-0.

2. Mamas M.A., Sperrin M., Watson M.C. et al. (2017) Do patients have worse outcomes in heart failure than in cancer? A primary care-based cohort study with 10 -year follow-up in Scotland. Eur. J. Heart Fail., 19(9): 1095-1104. doi: 10.1002/ejhf.822.

3. Вотчал Б.Е., Слуцкий М.Е. (1973) Сердечные гликозиды. М.: Медицина, 197 с

4. SOLVD Investigators, YusufS., Pitt B. et al. (1991) Effect of enalapril on survival in patients with reduced left ventricular ejection fractions and congestive heart failure. N. Engl. J. Med., 325(5): 293-302. doi: 10.1056/NEJM199108013250501.

5. Воронков Л.Г. (2007) Інгібітори АПФ та $\beta$-адреноблокатори у лікуванні хронічної серцевої недостатності: клінічна роль таметодологіязастосування. Раціональна фармакотерапія, 2(3).

6. Zannad F.,McMurray J.J., Krum H. etal. (2011) Eplerenone in patients with systolicheartfailure and mild symptoms. N. Engl. J. Med., 364(1): 11-21. doi: 10.1056/NEJMoa1009492.

7. Albaghdadi M, Gheorghiade M, Pitt B. (2011) Mineralocorticoid receptor antagonism: therapeutic potential in acute heart failure syndromes. Eur. Heart J.; 32(21): 2626-33. doi: 10.1093/eurheartj/ ehr170.

8. McMurray J.J., Packer M., Desai A.S. et al. (2014) Angiotensin-Neprilysin Inhibition versus Enalapril in Heart Failure. N. Engl. J. Med., 371: 993-1004.

9. Miller R.J.H., Howlett J.G., Fine N.M. (2020) A Novel Approach to Medical Management of Heart Failure With Reduced Ejection Fraction. Can. J. Cardiol.; 37(4): 632-643. doi: 10.1016/j. cjca.2020.12.028.

10. Ponikowski P., Voors A.A., Anker S.D. et al. (2016) ESC Guidelines for the diagnosis and treatment of acute and chronic heart failure: The Task Force for the diagnosis and treatment of acute and chronic heart failure of the European Society of Cardiology (ESC). Eur. Heart J., 37(27): 2129-2200.

11. Voronkov L.G., Berezin O.Ye., Amosova K.M. et al. (2020) Heart failure in patients with diabetes. Recommendations of the Ukrainian Association of Cardiology Ukrainian and the Association of Heart Failure Specialists. Ukr. Cardiol. J., 27(3): 1-33. (In Ukr.)

12. Writing Committee, Maddox T.M., Januzzi J.L.Jr. et al. (2021) 2021 Update to the 2017 ACC Expert Consensus Decision Pathway for Optimization of Heart Failure Treatment: Answers to 10 Pivotal Issues About Heart Failure With Reduced Ejection Fraction: A Report of the American College of Cardiology Solution Set Oversight Committee. J. Am. Coll. Cardiol., 77(6): 772-810. doi: 10.1016/j. jacc.2020.11.022.

13. McMurray J.J.V., Solomon S.D., Inzucchi S.E. etal. (2019) Dapagliflozin in Patients with Heart Failure and Reduced Ejection Fraction. N. Engl. J. Med., 381(21): 1995-2008.

14. Packer M., Anker S.D., Butler J. et al. (2020) Cardiovascular and Renal Outcomes with Empagliflozin in Heart Failure. N. Engl. J. Med., 383(15): 1413-1424. doi: 10.1056/NEJMoa2022190.

15. BhattD.L., VermaS.,Braunwald E. (2019)The DAPA-HFTrial:AMomentousVictory in theWar against Heart Failure. Cell Metab., 30(5): 847-849. doi: 10.1016/j.cmet.2019.10.008

16. Lee A.K., Warren B., Lee C.J. et al. (2018) The Association of Severe Hypoglycemia With Incident Cardiovascular Events and Mortality in Adults With Type 2 Diabetes. Diabetes Care, 41(1): 104-111. doi.org/10.2337/dc17-1669.

17. Zannad F., Ferreira J.P., Pocock S.J. et al. (2020) SGLT2 inhibitors in patients with heart failure with reduced ejection fraction: a meta-analysis of the EMPEROR-Reduced and DAPA-HF trials. Lancet, 396(10254): 819-829. doi: 10.1016/S0140-6736(20)31824-9.

18. Heerspink H.J.L., Stefánsson B.V., Correa-Rotter R. et al. (2020) Dapagliflozin in Patients with Chronic Kidney Disease. N. Engl. J. Med., 383: 1436-1446. D0I: 10.1056/NEJMoa2024816. 